\title{
The relationship between self-efficacy and reading proficiency of first-year students: An exploratory study
}

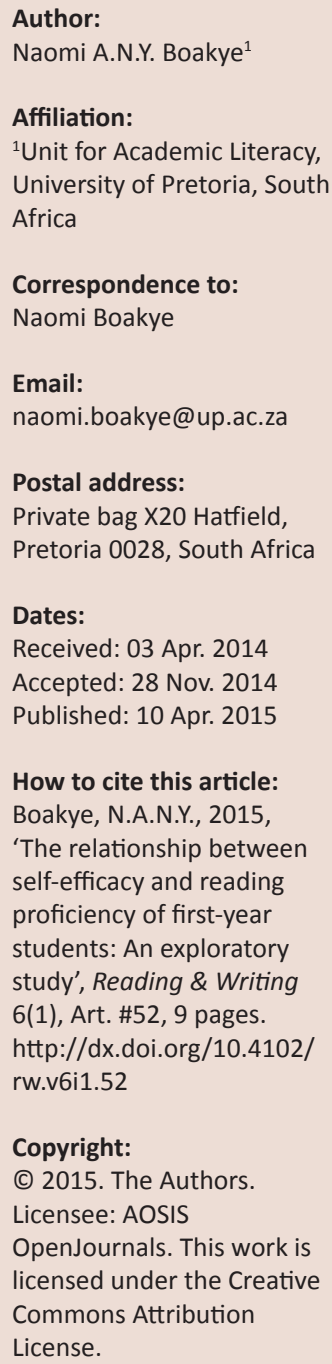

Self-efficacy, which is the belief about one's ability to perform a task successfully, has been widely acknowledged as important in learning. This affective factor, though not explicitly evident, has been said to play an important role in academic performance. However, its role in reading development has not been widely investigated. To determine the relationship between self-efficacy and reading proficiency, a study was conducted with first-year students in a South African tertiary institution. Students' self-efficacy levels were elicited through a questionnaire and their reading proficiency was obtained through the Test of Academic Literacy levels (TALL), which essentially assesses reading proficiency. An analysis of variance showed a robust relationship between reading self-efficacy and reading proficiency for this cohort of students. Regression analysis conducted with other affective factors showed selfefficacy as the best predictor of students' reading proficiency. Results are discussed as they relate to previous research and recommendations are made to include the development of self-efficacy in reading instruction.

\section{Introduction}

It has been widely acknowledged that self-efficacy, which is the belief in one's ability to successfully perform a task, plays an important role in learning (Amil 2000; Bandura 1986; Liem, Lau \& Nie 2008; Loo \& Choy 2013; Pajares 2000; Schunk 1991; Williams \& Takaku 2011). Pajares (2000) asserts that a learner's self-efficacy influences his or her academic performance. Studies by researchers such as Amil (2000), Hutchison-Green, Follman and Bodner (2008), Liem et al. (2008), Jones, Paretti, Hein, and Knot (2010), Mizumoto (2012) and Usher and Pajares (2006), have also shown a positive and significant correlation between self-efficacy and academic achievement. A number of researchers (e.g. Margolis \& McCabe 2004, 2006; Pajares 2006) have pointed out that without sufficiently high beliefs that they have the ability to succeed, many struggling leaners will not put in the effort necessary to attain success in academic tasks.

Although various research studies have emphasised the role of self-efficacy in learning, its role in relation to reading development has not been widely investigated. This could be due to the fact that reading researchers and instructors are more concerned about the explicit, cognitive aspects of reading, such as the use of strategies for comprehension. Although the use of strategies and other cognitive aspects of reading are acknowledged as important, other underlying factors such as self-efficacy may be equally important in reading development. As learning is largely dependent on reading, the relationship between self-efficacy and reading proficiency should be a high point of focus in education. Yet this is not the case, as the influence of self-efficacy in reading development has been largely ignored.

In order to shed more light on students' reading self-efficacy, especially at tertiary level where reading research is lacking, a study was undertaken with first year university students to examine the relationship between reading self-efficacy and reading proficiency. The article reports on this study and argues for the inclusion of self-efficacy development in reading instruction. First, the concept of self-efficacy is clearly defined, followed by a discussion of its role in learning and the role it may play in reading development. The study is then presented and recommendations are made based on the findings.

\section{Self-efficacy}

Bandura (1997:3) defines self-efficacy as the 'beliefs in one's capabilities to organise and execute the courses of action required to produce given attainments'. According to him, the level of selfefficacy will determine whether a task will be initiated and completed. A learner with high selfefficacy will be motivated to put in more effort, persist longer and complete a given task. As a result, self-efficacy and motivation are perceived to have a bidirectional relationship. According 
to reading researchers (e.g. Grabe \& Stoller 2002; Guthrie \& Wigfield 2000) self-efficacy influences motivation, promotes strategy use and increases learner autonomy. Similarly, reading motivation promotes frequent reading, which contributes to the use of appropriate reading strategies and high self-efficacy (Guthrie \& Wigfield 2000). Appropriate and well-orchestrated strategy use in reading and learning increases self-efficacy and motivation, and also contributes to a high level of comprehension in reading, which may lead to better academic performance. Self-efficacy has been perceived to emanate from several sources.

\section{Sources of self-efficacy}

Self-efficacy is said to develop from four main sources: mastery experiences, vicarious experiences, social persuasion and emotional arousal (Bandura 1997; Usher \& Pajares 2006):

- Mastery experience refers to the judgement of competence based on one's own previous attainment in a related task. As Bandura (1997:192) explains, success raises mastery expectations, whereas repeated failures lower them, particularly if the mishap occurs early in the course of the events.

- Vicarious experience refers to observations of someone else's attainment in a related task (Usher \& Pajares 2006). Bandura (1977) explains that, although this source of selfefficacy is weaker than mastery experience, in certain contexts, it may play a crucial role. For example, when a learner is placed in an unfamiliar environment, seeing others perform could raise his or her efficacy levels.

- Social persuasion is the feedback, judgements, and appraisals from significant others about one's participation in a related task (Usher \& Pajares 2006). Bandura (1997) points out that this source of self-efficacy is not strong enough to make a significant impact on efficacy beliefs because it does not provide an authentic experiential base. However, in conjunction with other sources, such as mastery and vicarious experiences, it can have a greater impact. Bandura (1997:79) explains that it is easier to sustain a sense of efficacy, especially when struggling with difficulties, if significant others express faith in one's capabilities than if they convey doubts'.

- Emotional arousal, which is the emotion or physical sensation (anxiety, fatigue, and composure) that one experiences whilst performing a particular task, could also contribute to self-efficacy levels (Usher \& Pajares 2006). High emotional arousal such as anxiety can impede performance. A learning environment with less anxiety and stress is more likely to promote learning than one with high anxiety and stress.

Quantitative and qualitative studies in several sources of selfefficacy have shown mastery experiences to have the greatest influence on self-efficacy (Bandura 1997; Hutchison-Green et al. 2008; Hutchison, Follman, Sumpter \& Bodner 2006; Lent, Lopez, \& Bieschke 1991; Lent, Lopez, Brown, \& Gore 1996; Phan 2012; Usher \& Pajares 2006). The explanation given by Bandura (1997) is that mastery experience is the most authentic evidence of one's ability to succeed. According to Bandura (1997) and Loo and Choy (2013), an important source of low self-efficacy is previous negative experiences in learning. Thus, students who have had a poor reading background and poor reading experiences will display low self-efficacy.

\section{Self-efficacy in learning}

In the academic setting, many studies have shown a positive and significant correlation between self-efficacy and academic achievement. Vogt (2008) conducted a study involving undergraduate engineering students and found that selfefficacy is a strong predictor of academic achievement. Loo and Choy (2013) found that self-efficacy sources correlated with maths achievement, and that mastery experience was found to be the main predictor of academic achievement in maths. Louise and Mistele (2011) concluded from their study that self-efficacy is a good predictor of achievement scores in science and maths. Amil (2000) used 'A' level economics students and found positive correlations between selfefficacy and academic performance. Liem et al. (2008) using high school English scores found that self-efficacy predicted learners' English test scores. The influence of self-efficacy on general academic achievement as well as in specific subject fields has been well-documented. However, research on selfefficacy in reading is limited.

\section{Self-efficacy in reading}

In relation to the definition of self-efficacy, reading selfefficacy could be defined as the beliefs students have in their ability to read successfully. The few studies conducted on reading self-efficacy have documented positive correlations between self-efficacy and reading achievement. Waleff (2010), using intermediate (Grades 4-6) learners in America, found a positive correlation between students' self-efficacy for reading and reading achievement. He found that students' self-efficacy corresponded with their grade level reading. In addition, Schunk and Rice (1991) found that using self-efficacy strategies such as providing students with clear goals for reading tasks and giving feedback on students' progress in reading increased reading self-efficacy. Templin's (2011) study with English Second Language (ESL) learners at the Trident University International (TUI) showed that self-efficacy sources predicted students' self-efficacy levels and their English Second Language (ESL) proficiency. Mills, Pajares, and Herron (2007) also found that university students' self-efficacy in French was positively related to their reading proficiency.

In an earlier study, Shell, Murphy, and Bruning (1989) examined undergraduate students in an American university and found that self-efficacy and outcome expectancy beliefs jointly accounted for significant variance in students' reading achievement, with self-efficacy being the stronger predictor in reading achievement and accounting for significant variance in writing. 
In Asia, similar correlations were found. Mizumoto (2012) found that students with high self-efficacy were active users of strategies, employed deep strategies and were meta-cognitively superior to those without it. Those who had average self-efficacy used shallow strategies and those with low self-efficacy were passive or non-users of reading strategies. Thus, he concludes that self-efficacy could promote the use of reading strategies.

In addition, learners' low self-efficacy can be linked to low reading proficiency, which in turn has a strong relationship with low socio-economic status (SES) by virtue of SES providing or not providing adequate and rich reading experiences. According to Pretorius $(2000,2007)$ and Taylor and Yu (2009) the majority of learners from low SES families are likely to attend poorly resourced public schools, receive poor reading instruction, have negative reading experiences and are thus likely to perform poorly in reading assessment.

Given the relationship between self-efficacy and academic achievement, and self-efficacy and reading performance documented by various researchers internationally, a study was conducted on the relationship between self-efficacy and reading achievement at a South African university. The study set out to determine if such a relationship can be confirmed with tertiary students in an African context. In addition, the results could be used in designing reading programmes and arguing for the inclusion of self-efficacy development in reading instructional programmes. To the best of my knowledge, the relationship between self-efficacy and reading achievement has not been extensively researched within the African context in order to persuade educators to seriously consider self-efficacy in reading instruction. Besides, this kind of study is required in the African context, where a number of students come from poor social and educational backgrounds, a factor that contributes to low self-efficacy levels. The findings of this study will indicate the extent to which educators should incorporate this affective factor in reading instruction.

\section{The study}

The aim of the study was to determine the relationship between reading self-efficacy and students' reading proficiency. The following questions were used for the study:

- What is the relationship between reading self-efficacy and the reading proficiency of first- year university students?

- Is reading self-efficacy the best predictor of students' reading proficiency?

- What is the relationship between self-efficacy and the home language of this cohort of first-year students?

The third question was included because a number of Indigenous South African Language (ISAL) speakers attend poorly resourced public schools and are from impoverished reading backgrounds, both at home and at school. As a result, these students may be experiencing low self-efficacy in reading and in learning.

\section{Methodology}

The main focus of the study was on students' self-efficacy in relation to their reading proficiency. The independent variable of students' home language was included to gain a better understanding of the students' needs, for the purpose of instruction. In addition, given the South African context where a number of students from certain language groups are predominantly from low socio-economic status (SES) families, this aspect was necessary to give more insight, as reading proficiency at school level is associated with SES factors and inappropriate reading instruction (Taylor \& Yu 2009; Pretorius 2002, 2007; Pretorius \& Lephalala 2011; Van Staden \& Howie 2010). A two-way ANOVA test was performed on the dependent variable (reading proficiency levels) and the independent variables of self-efficacy and students' home language.

\section{Instrument}

A questionnaire consisting of a 5-point-likert scale (positive to negative) and the Test of Academic Literacy Levels (TALL) were used as instruments for data collection. Whereas students' reading proficiency was determined by TALL, their self-efficacy levels were determined by the questionnaire. The TALL, a reliable test (Weideman 2006), which essentially assesses reading proficiency, was used to determine students' risk group. According to Weideman (2006) the TALL has shown a remarkable degree of reliability with an average Cronbach alpha of .93 across three institutions, between 2004 and 2006. The TALL is a placement test intended to channel students, if so required, into appropriate academic literacy support courses. It determines students' risk of failure, academically. The self-efficacy questions were extracted from a longer questionnaire comprising other affective factors such as motivation, attitude and interest. The questions for the questionnaire were compiled using questions from Grabe and Stoller (2002), Guthrie, Wigfield and Von Secker (2000), and other questions specific to the context. The questionnaire on self-efficacy elicited responses on students' beliefs in their reading capabilities. In other words, it measured their awareness of the challenges they face as readers and the confidence they have in themselves to undertake reading tasks successfully. The longer questionnaire was first piloted, and questions that were not valid were removed. The reliability of the self-efficacy questions was 0.87 , which is acceptable. At the end of the questionnaire students had to select their home language from the options: English, Afrikaans, Indigenous South African Language (ISAL) or other (other languages outside South Africa).

\section{Participants}

Two groups of first year students ('low risk' and 'high risk' as determined by the TALL) participated in the study. The 'high risk' group consisted of students who were deemed to be at extremely high risk or at high risk of failure, academically. Students in this 'high risk' group register for a compulsory generic academic literacy module, whereas students in the 
'low risk' group, who are deemed to be at low or negligible risk of failure, register for a language-related module, usually academic reading or academic writing. The number of students who answered the questionnaire on self-efficacy from the two groups was 1816 in total. There were 659 students in the 'low risk' group and 1009 in the 'high risk' group. There were 148 students in the borderline group, but these students had to rewrite the test to be placed in either the 'high or low risk' group. They were therefore not included in the discussion.

\section{Procedure/data collection}

The questionnaire was administered to all first-year students in the Unit for Academic Literacy registered for either the compulsory academic literacy module or the elective academic reading module. The two modules were chosen in order to involve both 'high and low risk' students. Students in the 'high risk' group answered the questionnaire during one class period in the last lecture week of the first semester. Students who were not in class on the day were excluded. Students in the 'low risk' group answered the questionnaire at the end of their first semester examination in the academic reading module. As participation was voluntary some students chose not to participate.

\section{Data analyses}

Descriptive statistics and Cronbach's coefficients were obtained for the self-efficacy questions. Cronbach's alpha was 0.87 , which was considered adequate for reliability. An ANOVA test was conducted to determine the relationship between the variables (i.e., students' reading self-efficacy and their reading proficiency as determined by the TALL).

In addition, a cumulative logit (regression) analysis was performed using the responses to the full questionnaire on motivation, attitude, interest and self-efficacy on one hand, and students' performance in the TALL on the other, to determine the extent to which self-efficacy predicts students reading ability amongst other affective factors.

\section{Findings}

As indicated in Table 1, students who spoke English and Afrikaans as a home language were in the majority in the 'low risk' group. In total these students were 779, which is $77 \%$ of the students in the 'low risk' group. The ISAL students were in the majority in the 'high risk' group with a total of 412 , which is $63 \%$ of the population in the 'high risk' group. The distribution of students' home language and their reading proficiency as determined by the TALL is given in Table 1.

\section{Research question 1}

Research question 1 relates to the relationship between reading self-efficacy and reading proficiency of this cohort of first-year university students. As shown in Table 2, the mean figures and standard deviations for self-efficacy and students' reading proficiency indicate a relationship between the two. Students in the 'high risk' group who are perceived to have poor reading proficiency indicated low self-efficacy (M 2.44 and 2.38), according to questionnaire responses. On the other hand, students in the 'low risk' group who are perceived to have relatively better reading proficiency, indicated relatively higher self-efficacy (M 2.09 and 1.75), according to the questionnaire responses.

As shown in Table 2, mean figures decreased from 2.44 to 1.75 , as proficiency levels increased. This means that selfefficacy aligned with students' reading proficiency: the lower their reported self-efficacy, the poorer their performance in the TALL and vice versa.

The ANOVA analysis showed a statistically significant relationship between literacy groups and students' selfefficacy $(F(4)=8.84 ; P<.0001)$. Students who were deemed by the TALL as having 'negligible risk' showed highly favourable levels of self-efficacy. On the other hand, students who were deemed to be at 'high risk' of failure academically, according to the TALL, indicated a lower

TABLE 1: Distribution of students' reading proficiency levels in relation to their home language.

\begin{tabular}{|c|c|c|c|c|c|c|}
\hline \multirow{2}{*}{$\begin{array}{l}\text { Variable } \\
\text { Reading proficiency levels/groups (TALL) }\end{array}$} & \multicolumn{3}{|c|}{ High risk } & \multicolumn{3}{|c|}{ Low risk } \\
\hline & Extremely high risk & High risk & Border-line & Low risk & Negligible risk & Total \\
\hline \multicolumn{7}{|l|}{ Home language } \\
\hline English & 18 & 36 & 9 & 298 & 125 & 486 \\
\hline Afrikaans & 29 & 75 & 35 & 308 & 48 & 495 \\
\hline ISAL & 140 & 272 & 85 & 137 & 16 & 650 \\
\hline Other & 33 & 56 & 19 & 63 & 14 & 185 \\
\hline Total & 220 & 439 & 148 & 806 & 203 & 185 \\
\hline
\end{tabular}

TALL, Test of Academic Literacy levels.

TABLE 2: Means and Standard Deviations for students' self-efficacy levels in relation to their reading proficiency.

\begin{tabular}{|c|c|c|c|c|c|c|c|c|}
\hline \multirow{3}{*}{$\begin{array}{l}\text { Variable } \\
\text { Reading proficiency levels/groups }\end{array}$} & \multicolumn{4}{|c|}{ High risk } & \multicolumn{4}{|c|}{ Low risk } \\
\hline & \multicolumn{2}{|c|}{ Extremely high risk } & \multicolumn{2}{|c|}{ High risk } & \multicolumn{2}{|c|}{ Low risk } & \multicolumn{2}{|c|}{ Negligible risk } \\
\hline & $\mathrm{M}$ & SD & $\mathrm{M}$ & SD & M & SD & M & SD \\
\hline Self-efficacy levels & 2.44 & 0.77 & 2.38 & 0.72 & 2.09 & 0.69 & 1.75 & 0.57 \\
\hline
\end{tabular}

M, mean; SD, standard deviation 
level of self-efficacy. The 'extremely high risk' students reported the lowest levels of self-efficacy, and were followed by those who were deemed to be at 'high risk'. Finally, students deemed to have 'negligible risk' of failure indicated the highest self-efficacy amongst this cohort of students. Table 3 shows the hierarchical progression. The Scheffe test for multiple progression shows the differences between the groups.

Regarding the research question as to whether there is a relationship between self-efficacy and reading proficiency, the ANOVA test showed a robust relationship $(p<.0001)$ between the two variables. Self-efficacy corresponded either positively or negatively with reading proficiency. Responses from the questionnaire aligned with students' performance in the TALL as shown in Table 3.

The means with similar letters are not statistically different. Thus 'extremely high risk' and 'high risk' students were not statistically different from each other, which is shown by the same letter, A. However, both 'extremely high risk' and 'high risk' students were statistically different from the 'low risk' students, as shown in the different letter, C. The 'low risk' students were also statistically different from the 'negligible risk' students as shown in a different letter, D. Thus students' performance in the TALL aligned with their reported selfefficacy levels.

The data analyses show that there is a significant relationship between students' self-efficacy levels and their reading. Students who reported low self-efficacy beliefs were also poor readers or had low reading ability, as indicated by the TALL. Thus, as much as these students were poor or struggling readers, they also had low self-efficacy levels.

\section{Research question 2}

Research question 2: Is reading self-efficacy the best predictor of students' reading proficiency? In addition to the ANOVA test, self-efficacy was also placed in a pool with other affective factors (i.e. attitude, motivation and interest) in a regression analysis to determine how best it predicts reading proficiency. Self-efficacy emerged as the strongest predictor of students' reading proficiency at a statistical significance of $p<0.0001$. In other words, the analysis showed that students' self-efficacy strongly indicated their proficiency levels in reading. When students' self-efficacy beliefs are high, their reading proficiency is also high. This relationship points to the need to improve students' self-efficacy concomitantly with

TABLE 3: Scheffe groupings and mean scores for literacy levels in relation to self-efficacy.

\begin{tabular}{|c|c|c|c|c|c|}
\hline \multicolumn{2}{|c|}{ Scheffe grouping } & \multicolumn{2}{|c|}{ Means and Self-efficacy levels } & \multirow{2}{*}{$\frac{N}{220}$} & \multirow{2}{*}{$\begin{array}{l}\text { Literacy level } \\
\text { Extremely high Risk }\end{array}$} \\
\hline - & A & 2.43 & Low & & \\
\hline - & A & 2.37 & Low & 439 & High Risk \\
\hline B & C & 2.19 & Low & 218 & Borderline \\
\hline - & C & 2.09 & High & 806 & Low Risk \\
\hline - & D & 1.75 & Highest & 203 & Negligible Risk \\
\hline
\end{tabular}

Note: Means with the same letter are not significantly different. cognitive reading instruction in order to achieve maximum results in developing students' reading proficiency.

There was an interaction amongst the three factors of home language, reading proficiency and self-efficacy levels at $(F(12)=1.77 ; p=0.0473)$. In other words, the relationship between students' self-efficacy levels and their reading proficiency was determined by their home language. Students who spoke ISAL as a home language were mostly in the 'high risk' group. This group indicated lower self-efficacy levels compared to the 'low risk' group. Although on the whole the 'high risk' group responded negatively to questions on self-efficacy, English and Afrikaans home language speakers who were placed in this group according to the TALL, were less negative in their responses than the ISAL speakers. It is interesting to note that amongst 'negligible risk' students, the ISAL speakers were the most positive in their responses to self-efficacy, compared to their Afrikaans and English counterparts. The interactions relating to students' responses to their self-efficacy levels are shown in Figure 1.

\section{Research question 3}

Research question 3 relates to the relationship between selfefficacy and the home language of this cohort of first-year students. Table 4 shows that students who spoke English and Afrikaans as home language indicated relatively better selfefficacy (English M, 1.99; Afrikaans M, 2.18) than the ISAL home language students (M, 2.28).

Whereas the English home language group indicated the highest self-efficacy levels, concomitant with their good performance in the TALL and indicative of better reading proficiency, the ISAL home language speakers reported relatively lower self-efficacy levels, which also aligned with their poor performance in the TALL (cf. Table 1).

Most of the ISAL home language speakers were in the 'high risk' group and reported low self-efficacy levels. Selfefficacy, therefore, has a direct relationship with students' reading proficiency and an indirect relationship through home language. This seems to be a 'double-edged sword' (low self-efficacy; poor reading proficiency) and calls for serious consideration of the relationship between students' self-efficacy and their reading proficiency when improving students' reading proficiency, especially the ISAL group.

\section{Discussion}

Students who were deemed to have negligible risk had high self-efficacy, which confirms the positive relationship between self-efficacy and reading proficiency. ISAL home language students who are deemed to be at extremely high risk or at high risk of failure academically, as indicated by the TALL, were consistently negative in the rating of their reading self-efficacy. Thus reading instruction for such students should also focus on improving their selfefficacy. 


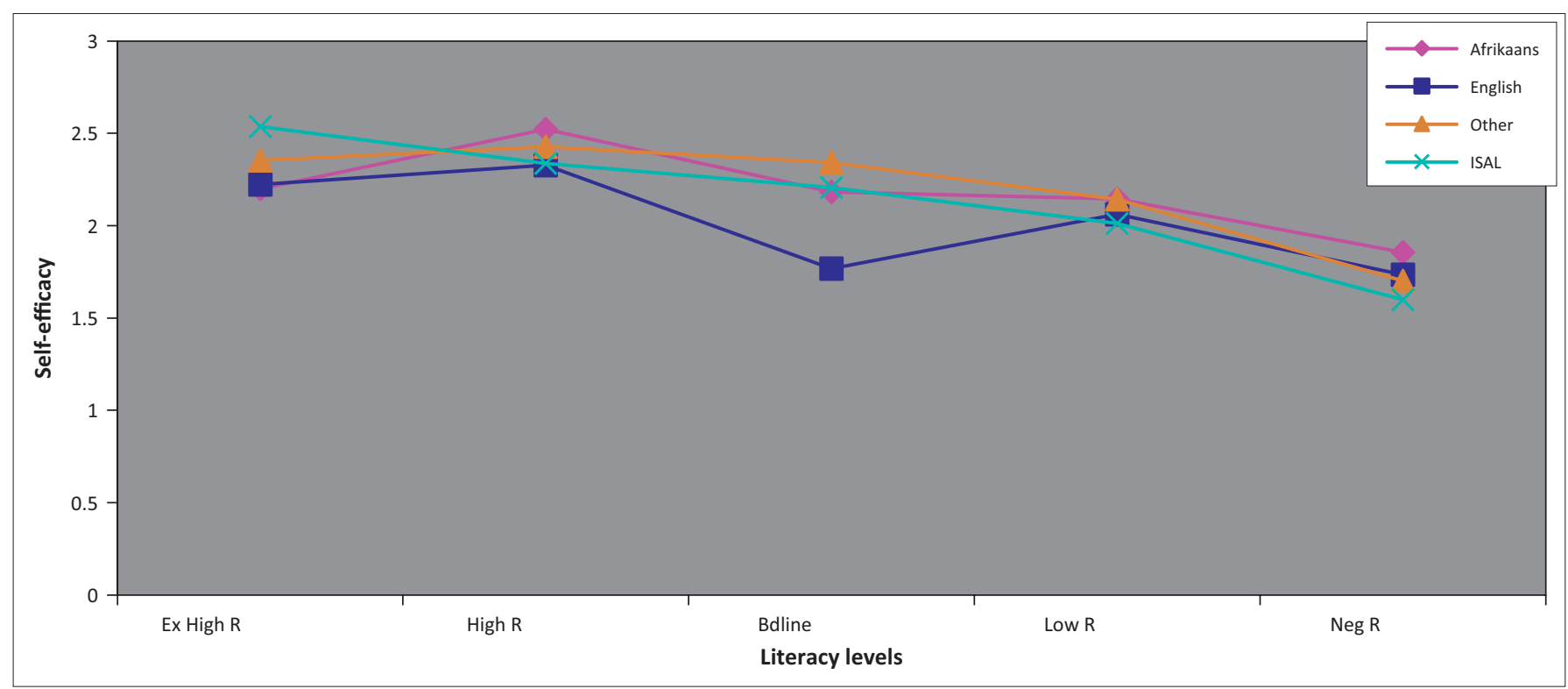

FIGURE 1: Interaction between literacy levels and students' home language in relation to their self-efficacy.

TABLE 4: Means and standard deviations for students' self-efficacy levels in relation to their home language.

\begin{tabular}{|c|c|c|c|c|c|c|c|c|}
\hline \multirow{2}{*}{$\begin{array}{l}\text { Home language groups } \\
\text { Variable }\end{array}$} & \multicolumn{2}{|c|}{ English } & \multicolumn{2}{|c|}{ Afrikaans } & \multicolumn{2}{|c|}{ ISAL } & \multicolumn{2}{|c|}{ Other } \\
\hline & $\mathbf{M}$ & SD & $\mathbf{M}$ & SD & M & SD & $\mathbf{M}$ & SD \\
\hline Self-efficacy levels & 1.99 & 0.67 & 2.18 & 0.74 & 2.28 & 0.72 & 2.25 & 77 \\
\hline
\end{tabular}

M, mean; SD, standard deviation

Explicit strategy instruction is said to improve self-efficacy (Pajares 2006), and therefore explicit instruction of various reading strategies (both processing and monitoring strategies) should be provided to these students on a continuous basis. Self-efficacy, which is the affective variant of metacognition (monitoring strategies), is known to be crucial for success in academic reading at tertiary level (Mills et al. 2007). Thus instruction on metacognition should be undertaken concurrently with the improvement of self-efficacy levels.

A robust relationship exists between self-efficacy and the reading proficiency of this cohort of students. The relation, determined by ANOVA tests on the responses to the selfefficacy questionnaire, showed that self-efficacy has both a direct relationship and an indirect relationship with reading proficiency. In addition, regression analysis showed selfefficacy as the strongest predictor of students' reading proficiency amongst other affective factors.

Self-efficacy seems to occupy a significant role in determining reading proficiency and thus should not be ignored in programmes aimed at improving students' reading proficiency. It is suggested that, at both school and tertiary levels, there should be a focus on addressing strategy use and self-efficacy levels in order to improve both cognitive and affective dimensions involved in reading development.

Another important factor that emerged from the survey was the relationship between students' self-efficacy and their home language. The relationship between students' home language and their self-efficacy levels was statistically significant. Worthy of note is the significant interaction between home language, proficiency or literacy levels and self-efficacy. ISAL home language students who were deemed to have negligible risk and are therefore proficient readers, indicated high self-efficacy (the highest of all the groups), whereas ISAL students identified as being at extremely high risk indicated the lowest self-efficacy of all the home language groups. Also, English home language students indicated high levels of self-efficacy. What needs to be pointed out here is that it is not the home language per se that influences students' self-efficacy and reading proficiency, but there seems to be a combination of factors that include SES, educational background, reading experience, and other socio-cultural factors associated with certain home language groups that influence reading proficiency. Given the low self-efficacy and poor reading proficiency of the majority of ISAL students, these students would need instruction that adequately and directly addresses their affective needs, whilst developing their cognitive reading abilities. As Pajares (2006) and Guthrie and Wigfield (2000) point out, selfefficacy enhancement is an important component of reading motivation.

Various techniques, such as learning goal orientation, feedback on progress, explicit strategy instruction, building mastery experience, using discipline-specific texts, and providing praise and rewards have been shown to improve self-efficacy. According to Guthrie and Klauda (2013) assuring students of success increases their self-efficacy. One way to do this is to provide competence support in the form of providing feedback on progress. 
Feedback on progress should be frequent and positive. Positive does not mean grading students highly when they do not deserve it, but rather that comments and suggestions should be encouraging and specific (Dörnyei 2001). In addition, an educator can emphasise learning goals by encouraging learners to focus on learning, understanding and achievement instead of focusing solely on grades (Guthrie \& Wigfield 2000; Margolis \& McCabe 2004).

Using discipline-specific texts also provides opportunities for self-efficacy improvement (Guthrie \& Klauda 2013). Although generic texts have their place in reading instruction, using discipline-specific texts, especially at tertiary level will provide background knowledge and relevance that will give students confidence of success.

Explicit strategy instruction also increases self-efficacy. Furthermore, students can only be confident about their capabilities when they are given clear directions and guidance on the task they are required to perform (Graham \& Macaro 2008; Guthrie \& Wigfield 2000). According to Mizumoto and Takeuchi (2009), teaching students strategies may increase their self-efficacy.

Moreover, positive mastery experience, which refers to one's judgement of competence or one's own previous attainment in a related task (Usher \& Pajares 2006) should be encouraged. According to Bandura (1977:193) 'successes raise mastery expectations; repeated failures lower them'.

Finally, praise and rewards may seem ordinary and simple, but according to researchers such as Dörnyei (2001) and Kumaravadivelu (2003), they provide opportunities for students to receive acknowledgement of success, which increase self-efficacy. In an interview with first- year students after a reading intervention programme in 2011, a number of the students reported on how motivating and confidence-building praises and rewards were to them (Boakye 2012). This was especially true of the 'high risk' students who reported that 'it makes you feel that you are good, especially in front of other students, and you put in more effort' (Boakye 2012:215). Although preschool learners are usually given stars for achievement, this practice is not carried on in the senior grades. The suggestion is for educators to include this practice, even if it is only acknowledging achievement and praising the student in the presence of other students. If tertiary students found the technique beneficial, learners in school would definitely benefit from it. However, since the 'low' risk group was not as enthusiastic as the 'high risk' group, it should be noted that not all students may perceive it positively. Nevertheless praise and rewards may assist in building the confidence and self-efficacy of low achievers.

\section{Conclusion}

The article has reported on the relationship between firstyear tertiary students' self-efficacy levels and their reading proficiency as shown in their reading performance in the TALL. Using the ANOVA test a robust relationship was found between self-efficacy and reading proficiency directly, and indirectly through the students' home language. ISAL students reported low self-efficacy levels, whereas English and Afrikaans home language groups reported higher selfefficacy levels. Also, 'high risk' students reported low selfefficacy and 'low risk' students reported high self-efficacy levels. Given the important role that self-efficacy plays in reading and in learning in general, it is recommended that reading instruction programmes should include the development of self-efficacy by focusing on learning goals, providing feedback on progress, developing explicit strategy instruction, giving praise and rewards and using disciplinespecific texts where possible.

The results suggest that self-efficacy exerts a potentially important affective influence on students' reading proficiency. Consideration of this possible influence is necessary for the creation of effective reading instruction. However, although self-efficacy relates to reading proficiency, Shell et al. (1989) point out that self-efficacy beliefs by themselves cannot directly cause reading achievement. Further research is therefore needed to investigate how self-efficacy beliefs affect the cognitive processes that are causally related to reading achievement. As a start to this investigation, Schunk and Swartz (1993) have reported from their studies that self-efficacy is associated with the use of specific reading strategies. Earlier researchers have pointed out that self-efficacy, presumably, may exert its influence by affecting motivation (Bandura 1986; Schunk 1991). There is a need to investigate how self-efficacy relates to measures of motivation and how the motivational measures affect, and are themselves affected by the strategies used during reading.

\section{Acknowledgements}

\section{Competing interests}

The author declares that she has had no financial or personal relationship(s) that may have inappropriately influenced her in writing this article.

\section{References}

Amil, M.B.M., 2000, 'Self-efficacy and academic performance in economics in the junior college', Unpublished Thesis, Nanyang Technical University, Singapore.

Bandura, A., 1977, 'Self-efficacy: Toward a unifying theory of behavioural change', Psychological Review 84(2), 191-215. http://dx.doi.org/10.1037/0033295X.84.2.191

Bandura, A., 1986, Social foundations of thought and action: A social cognitive theory, Prentice Hall, Englewood Cliffs.

Bandura, A., 1997, Self-efficacy: The exercise of control, W. H. Freeman and Company, New York.

Boakye, N.A., 2012, 'A socio-affective approach to improving students' reading comprehension abilities', PhD thesis, University of Pretoria, Pretoria.

Dörnyei, Z., 2001, Motivational strategies in the language classroom, Cambridge University Press, Cambridge. http://dx.doi.org/10.1017/СBO9780511667343

Grabe, W. \& Stoller, F., 2002, Teaching and researching reading, Pearson Education, London.

Graham, S. \& Macaro, E., 2008, 'Strategy instruction in listening for lower-intermediate learners of French', Language Learning 58(4), 747-783. http://dx.doi.org/10.1111/ j.1467-99222008.00478.x 
Guthrie, J.T. \& Wigfield, A., 2000, 'Engagement and motivation in reading', in M.L. Kamil, P.B. Mosenthal, P.D. Pearson \& R. Barr (eds.), The handbook of reading research, vol. 3, pp. 403-420, Lawrence Erlbaum Associates, Mahwah, New Jersey.

Guthrie, J.T. \& Klauda, S.L., 2013, Handbook of individual differences in reading, Routledge Publishers, New York.

Guthrie, J.T., Wigfield, A. \& Von Secker, C., 2000, 'Effects of integrated instruction on motivation and strategy use in reading', Journal of Educational Psychology 92, 331-341. http://dx.doi.org/10.1037/0022-0663.92.2.331

Hutchison, M.A., Follman, D.K. Sumpter, M. \& Bodner, G.M., 2006, 'Factors influencing the self-efficacy beliefs of first-year Engineering students', Journal of Engineering Education 95(1),39-47. http://dx.doi.org/10.1002/j.2168-9830.2006.tb00876.x

Hutchison-Green, M.A., Follman, D.K. \& Bodner, G.M., 2008, 'Providing a voice: Qualitative investigation of the impact of a first-year Engineering experience on students' efficacy', Journal of Engineering Education 97(2), 177-190.

Jones, B.D., Paretti, M.C., Hein, S.F. \& Knot, T.W., 2010, 'An analysis of motivation constructs with first-year engineering students: Relationships among expectancies, values, achievement and career plans', Journal of Engineering Education 99(4), 319-336. http://dx.doi.org/10.1002/j.2168-9830.2010.tb01066.x

Kumaravadivelu, B., 2003, Beyond methods: Macrostrategies for language teaching Yale University Press, New Haven.

Lent, R.W., Lopez, F.G. \& Bieschke, K.J., 1991, 'Mathematics self-efficacy: Sources and relation to science-based career choice', Journal of Counseling Psychology 38(4), 424-430. http://dx.doi.org/10.1037/0022-0167.38.4.424

Lent, R.W., Lopez, F.G., Brown, S.D. \& Gore, P.A., 1996, 'Latent structure of the sources of mathematics self-efficacy', Journal of Vocational Behaviour 49(3), 292-308. http://dx.doi.org/10.1006/jvbe.1996.0045

Liem, A.D., Lau, S. \& Nie, Y., 2008, 'The role of self-efficacy, task value and achievement goals in predicting learning strategies, task disengagement, peer relationship and achievement outcome', Contemporary Educational Psychology 33, 486-512. http://dx.doi.org/10.1016/j.cedpsych.2007.08.001

Loo, C.W. \& Choy, J.L.F., 2013, 'Sources of self-efficacy influencing academic performance of engineering students', American Journal of Educational Research 1(3), 86-92. http://dx.doi.org/10.12691/education-1-3-4

Louis, R.A. \& Mistele, J.M., 2011, 'The differences in scores and self-efficacy by student gender in Mathematics and Science', International Journal of Science and Mathematics Education, viewed 05 March 2014, from http://link.springer com/search?query=Louis+\%26+Mistele+2011\&search-within=Journal\&facetpublication-title=International+Journal+of+Science+and+Mathematics

Margolis, H. \& McCabe, P., 2004, 'Self-efficacy: A key to improving the motivation of struggling learners', The Clearing House 77(6), 241-249. http://dx.doi. org/10.3200/TCHS.77.6.241-249

Margolis, H. \& McCabe, P., 2006, 'Improving self-efficacy and motivation: What to do, what to say', Intervention in School and Clinic 41(4), 218-227. http://dx.doi.org/10 $.1177 / 10534512060410040401$

Mills, N.A., Pajares, F. \& Herron, C., 2007, 'Self-efficacy of college intermediate French students: Relation to achievement and motivation', Language learning 57(3), 417-442. http://dx.doi.org/10.1111/j.1467-9922.2007.00421.x

Mizumoto, A., 2012, 'Exploring the effects of self-efficacy on vocabulary learning strategies', Studies in Self-Access Learning Journal 3(4), 423-437.

Mizumoto, A. \& Takeuchi, O., 2009, 'Examining the effectiveness of explicit instruction of vocabulary learning strategies with Japanese EFL university students', Language Teaching Research 13(4), 425-449. http://dx.doi.org/10.1177/1362168809341511
Pajares, F., 2000, 'Self-efficacy beliefs and current directions in self-efficacy research', viewed n.d., from http://www.uky.edu/ eushe2/Pajares/effchapter.html

Pajares, F., 2006, 'Self-efficacy during childhood and adolescence: Implications for teachers and partners', in F. Pajares \& T. Urden (eds.), Self-efficacious beliefs of adolescents, pp. 339-367, Information Age Publishing, Greenwich.

Phan, H.P., 2012, 'Relations between informational sources, self-efficacy and academic achievement: A developmental approach', Educational Psychology 32(1), 81-105. http://dx.doi.org/10.1080/01443410.2011.625612

Pretorius, E.J., 2000, 'Inference generation in the reading of expository texts by university students', PhD thesis, University of South Africa, Pretoria.

Pretorius, E.J. 2002, 'Reading ability and academic performance in South Africa: Are we fiddling while Rome is burning?', Language Matters 33, 91-103. http://dx.doi. org/10.1080/10228190208566183

Pretorius, E.J. 2007, 'Looking into the seeds of time: Developing academic literacy in high poverty schools', Ensovoort 11(2), 105-125.

Pretorius, E.J. \& Lephalala, M., 2011, 'Reading comprehension in high-poverty schools: How should it be taught and how well does it work?', Per Linguam 27(2), 1-24.

Schunk, D.H., 1991, 'Self-efficacy and academic motivation', Educational Psychologist 26, 207-231. http://dx.doi.org/10.1207/s15326985ep2603\&4_2

Schunk, D.H. \& Rice, J.M., 1991, 'Learning goals and progress feedback during reading comprehension instruction', Journal of Reading Behaviour 23, 351-364.

Schunk, D.H. \& Swartz, C.W., 1993, 'Goals and progress feedback: Efforts on selfefficacy and writing achievement', Contemporary Educational Psychology 18 337-354.

Shell, D.F, Murphy, C.C \& Bruning, R.H., 1989, 'Self-efficacy and outcome expectancy mechanisms in reading and writing achievement', Journal of Education Psychology 8(1), 91-100. http://dx.doi.org/10.1037/0022-0663.81.1.91

Taylor, S. \& Yu, D., 2009, 'Socio-economic status and educational achievement: Does education provide a stepping stone out of poverty in South Africa?', Transformation Audit, 66-75.

Templin, S.A, 2011, 'Examining the effects of self-efficacy sources on English as a Second Language (ESL): Self-efficacy beliefs and ESL proficiency', PhD thesis, Trident University International (TUI), NY. Retrieved from ProQuest Dissertations and Theses. Database. (UMI No. 3327832).

Usher, E.L. \& Pajares, F., 2006, 'Sources of academic and self-regulatory efficacy beliefs of entering Middle School students', Contemporary Educational Psychology 31(2), 125-141. http://dx.doi.org/10.1016/j.cedpsych.2005.03.002

Van Staden, S. \& Howie, S., 2010, 'South African teacher profiles and emerging teacher factors: The picture painted by PIRLS 2006', Reading and Writing 1(1), 47-60.

Vogt, C.M., 2008, 'Faculty as a critical juncture in student retention and performance in engineering programs', Journal of Engineering Education 97(1), 27-36. http:// dx.doi.org/10.1002/j.2168-9830.2008.tb00951.x

Waleff, M.L., 2010 'The relationship between mastery orientation goals, student selfefficacy for reading achievement in intermediate level learners in a rural district', PhD thesis, Walden University, Minneapolis, MN. Retrieved from ProQuest PhD thesis, Walden University, Minneapolis, MN.
Dissertations and Theses. Database number (3427217).

Weideman, A., 2006, 'Assessing academic literacy: A task-based approach', Language Matters 37(1), 81-101. http://dx.doi.org/10.1080/10228190608566253

Williams, J.D. \& Takaku, S., 2011, 'Help seeking, self-efficacy, and writing performance among college students', Journal of writing research 3(1), 1-18. 


\section{Appendix}

\section{Questionnaire on self-efficacy.}

\begin{tabular}{|c|c|c|c|c|c|c|c|c|}
\hline \multicolumn{3}{|c|}{ Beliefs about reading ability /Reading self-efficacy } & 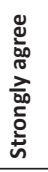 & 这 & 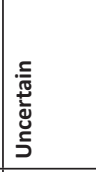 & 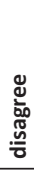 & 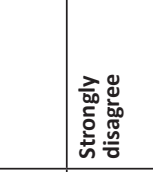 & \\
\hline \multicolumn{3}{|c|}{ 23. I think I read well and with understanding } & 1 & 2 & 3 & 4 & 5 & V23 \\
\hline \multicolumn{3}{|c|}{$\begin{array}{l}\text { 24. I read slowly so I have problems with } \\
\text { understanding }\end{array}$} & 1 & 2 & 3 & 4 & 5 & V24 \\
\hline \multicolumn{3}{|c|}{$\begin{array}{l}25 . \text { I have difficulty in completing the reading } \\
\text { assignments given to me }\end{array}$} & 1 & 2 & 3 & 4 & 5 & V25 \\
\hline \multicolumn{3}{|c|}{$\begin{array}{l}26 . \text { I read slowly so it makes me tired } \\
\text { and bored }\end{array}$} & 1 & 2 & 3 & 4 & 5 & V26 \\
\hline \multicolumn{3}{|c|}{$\begin{array}{l}\text { 27. I have difficulty in understanding words } \\
\text { ( } 50 \% \text { or more) in my reading assignments }\end{array}$} & 1 & 2 & 3 & 4 & 5 & V27 \\
\hline \multicolumn{3}{|c|}{$\begin{array}{l}28 . \text { I have to translate what I read into my } \\
\text { home language before I really understand }\end{array}$} & 1 & 2 & 3 & 4 & 5 & V28 \\
\hline \multicolumn{3}{|c|}{$\begin{array}{l}\text { 29. I have difficulty in understanding idiomatic } \\
\text { Language }\end{array}$} & 1 & 2 & 3 & 4 & 5 & V29 \\
\hline \multicolumn{3}{|c|}{$\begin{array}{l}\text { 31. I have difficulty in extracting the main } \\
\text { points in what I read. }\end{array}$} & 1 & 2 & 3 & 4 & 5 & V31 \\
\hline \multicolumn{3}{|c|}{$\begin{array}{l}\text { 32. I find it difficult to summarise a text in my } \\
\text { own words }\end{array}$} & 1 & 2 & 3 & 4 & 5 & V32 \\
\hline \multicolumn{9}{|l|}{ Personal information } \\
\hline 68. TALL performance & Ext high risk & High risk & \multicolumn{2}{|c|}{ Borderline } & Low risk & & Negligible risk & V68 \\
\hline 69. Home language & Eng & Afr & & & Other & & & V69 \\
\hline
\end{tabular}

Thank you for filling in the questionnaire. 